\title{
AN OVERVIEW OF THE EFFECTS OF IRISIN ON METABOLIC DISORDERS
}

\author{
Hatice Tuğçe BERBEROĞLU' ${ }^{1}$, Aysun HACIŞEVKİ² \\ ${ }^{I}$ KTO Karatay University, College of Health Sciences, Department of Nutrition and Dietetics, Konya, Turkey \\ ${ }^{2}$ Gazi University, Faculty of Pharmacy, Department of Biochemistry, Ankara, Turkey
}

\begin{abstract}
Obesity and obesity-related diseases including insulin resistance and metabolic syndrome (MetS) pose a great risk for cardiovascular disease development. Skeletal muscle as an endocrine organ has pivotal role on secreting physiological factors such as hormones and myokines. Irisin that is one of these myokines also known as hormone is secreted mainly from muscle tissue in response to exercise. It is dependent to fibronectin type III-containing protein 5 (FNDC5) that is a membrane protein and encoded by FNDC5 gene. After discovering of FNDC5, metabolic effects of irisin have been investigated so far. Irisin has mainly effects on muscle, adipose tissue, pancreas, liver, nervous system and bone. In studies conducted to date, obtained findings regarding the relationship of irisin status with obesity, insulin resistance and MetS are contradictory. Although irisin concentration was found higher in individuals with metabolic disorders in some studies, lower irisin concentration were observed in some other studies. Additionally, any receptors for irisin molecule hasn't yet discovered. Therefore, it is thought that the discovery of irisin molecule receptors and the determining of the tissues where these receptors are localized will be useful in understanding the mechanism of action of the irisin. In this review, we aimed to investigate potential effects of irisin on obesity, insulin resistance and MetS and additionally to examine underlying mechanisms of the association between circulating irisin and metabolic disorders.
\end{abstract}

Keywords: Irisin, obesity, metabolic syndrome. FNDC5, metabolic disorders

\section{İRISINIIN METABOLİK BOZUKLUKLAR ÜZERINDEKİ ETKILLERINE GENEL BİR BAKIŞ}

\section{ÖZET}

İnsülin direnci ve metabolik sendrom (MetS) dahil olmak üzere obezite ve obezite ile ilgili hastalıklar, kardiyovasküler hastalık gelişimi için büyük bir risk oluşturmaktadır. Bir endokrin organ olarak iskelet kası, hormonlar ve miyokinler gibi fizyolojik faktörlerin salgılanmasında çok önemli bir role sahiptir. Hormon olarak da bilinen bu miyokinlerden irisin, egzersize yanıt olarak başlıca kas dokusundan salgılanır. Bir membran proteini olan ve FNDC5 geni tarafindan kodlanan fibronektin tip III içeren protein 5'e (FNDC5) bağımlıdır. FNDC5 keşfedildikten sonra, şimdiye kadar irisinin metabolik etkileri araştırılmıştır. Irisin esas olarak kas, yağ dokusu, pankreas, karaciğer, sinir sistemi ve kemik üzerine etkilere sahiptir. Bugüne kadar yapılan çalışmalarda, irisin durumunun obezite, insülin direnci ve MetS ile ilişkisine dair elde edilen bulgular çelişkilidir. Bazı çalışmalarda metabolik bozukluğu olan kişilerde irisin konsantrasyonu daha yüksek bulunmasına rağmen, bazı çalışmalarda daha düşük irisin konsantrasyonu gözlenmiştir. Ek olarak, irisin molekülü için herhangi bir reseptör henüz keşfedilmedi. Bu nedenle irisin molekülü reseptörlerinin keşfi ve bu reseptörlerin lokalize olduğu dokuların belirlenmesinin, irisinin etki mekanizmasının anlaşılmasında faydalı olacağı düşünülmektedir. Bu derlemede; irisinin obezite, insülin direnci ve MetS üzerindeki potansiyel etkilerini araştırmayı ve ayrıca dolaşımdaki irisin ile metabolik bozukluklar arasındaki ilişkinin altında yatan mekanizmaları incelemeyi amaçladık.

Anahtar kelimeler: İrisin, obezite, metabolik sendrom, FNDC5, metabolik bozukluklar

İletişim/Correspondence

Aysun HACIŞEVKi

Gazi University, Faculty of Pharmacy,

Department of Biochemistry, Ankara, Turkey
E-posta: abozkir@gazi.edu.tr

Geliş tarihi/Received: 15.01.2021

Kabul tarihi/Accepted: 04.05.2021

DOI: $10.52881 /$ gsbdergi.861600 


\section{INTRODUCTION}

Obesity that is common today worldwide is defined by the World Health Organization (WHO) as excessive fat accumulation that deteriorates human health. In 2016, it is reported that 650 million adults over the age of 18 have obesity (1). Insulin resistance is defined as the secretion of more insulin than usual to keep the blood glucose level at normal levels as a result of the decrease in insulin sensitivity or the response of the tissues to insulin (2). Insulin resistance has been shown to be linked to increased obesity, Type 2 Diabetes Mellitus (T2DM), serum triglyceride level, cardiovascular disease, and decreased high-density lipoprotein cholesterol (HDL-C). In addition, insulin resistance is considered to be a major contributor of MetS pathogenesis (3). MetS is defined as the cluster of metabolic disorders including abdominal obesity, hyperlipidemia, hypertension and hyperglycemia. All these problems are associated with obesity and pose a risk for the development of cardiovascular diseases (4). The exact mechanism of MetS is not fully understood. However obesity, insulin resistance, ethnicity, genetic disposition and sedentary lifestyle are thought to be pivotal risk factors for MetS development (5).

The skeletal muscle is known for its role in providing physical movement, but in recent studies there is increasing evidence that it may have important roles in the secretion of various physiological factors. Skeletal muscle is known as an endocrine organ because it secretes various hormones called myokines (6). Myokines are considered to have various functions such as myogenesis, fatty acid oxidation, endothelial function and turning the kind of adipose tissue from white to brown (6).
In 2012 Boström et al., (7) has discovered that exercise induces FNDC5 secretion from muscle tissue. This is a membrane protein and it is encoded by FNDC5 gene (8). In response to exercise, FNDC5 is synthesized from peroxisome proliferatoractivated gamma coactivator- $1 \alpha$ (PGC- $1 \alpha)$ (7). While the C-terminal of FNDC5 is located in cytoplasm, N-terminal of FNDC5 is released into circulation during proteolytic cleavage as irisin (7). Therefore, irisin is formed from FNDC5, after proteolysis. As the proteolytic product of the FNDC5 protein, (9) irisin is expressed from skeletal muscle into the blood (10). Irisin which is an important factor for balancing body temperature (10) by causing white adipose tissue to browning, comprises 112 amino acids and its weight is $12 / \mathrm{kDa}$ (7). Irisin increases energy expenditure by inducing thermogenesis (11). No any specific receptor for the irisin has been discovered yet (12). Although its main source is skeletal muscle and adipose tissue; it is also synthesized in tissues like heart tissue, in cranial arteries, kidneys, tongue, rectum were discovered (13). It can be regarded as a hormone due to its paracrine, autocrine and endocrine effects (14).

After the isolation of irisin from muscle tissue by Böstrom et al., (7) many studies have been carried out on this molecule until today. In these studies, important effects of exercise on health by increasing the concentration of the circulating irisin have been investigated. Irisin has effects on many tissues as adipose tissue, nervous system and bones. Its various effects on inflammation and carcinogenesis also have been described (12). Irisin has important roles in improving metabolic diseases by increasing mitochondrial density and metabolic rate in myocytes and adipocytes 
(15). Irisin has positive effects on bones as it induces bone formation, decreases fracture risk and increases osteoblast differentiation (12). In addition, irisin has positive effects on the nervous system by maintaining neurogenesis, reducing some proinflammatory cytokines and preventing neuron damage by reducing oxidative stress (12). In the liver, it has important roles in modulating glucose homeostasis. It serves on regeneration and function of beta cells in pancreas, maintains beta cell survival and increases secretion of some hormones including insulin and glucagon (Figure 1) (11). In addition, it is considered to be of great importance in terms of the cure of obesity and various diseases associated with obesity (16). The irisin molecule is thought to be a potential agent for use in the treatment of many diseases (17). In this review, we aimed to examine the metabolic effects of irisin molecule on obesity, insulin resistance and MetS. Also underlying mechanisms of the association between irisin and obesity and obesity related metabolic disorders will be evaluated.

\section{Irisin\&Obesity}

Slight elevated irisin levels with exercise leads to increased energy expenditure without any change in movement or food consumption. This has an important role in body weight control and balancing blood glucose level (18). Irisin activates mitochondrial uncoupling protein 1 (UCP1) (11) which is also called as thermogenin (12). Increased UCP1 expression also inhibits ATP synthesis (10) and increases thermogenesis by causing browning in white adipose tissue. All of these contribute to body weight control $(11,19,20)$. The suppression of the gene expression of the irisin induces the development of adipogenesis by decreasing the UCP1 expression (11). Additionally it induces lipolysis via cAMP-protein kinase A (PKA)-hormone sensitive lipase (HSL)/perilipin pathway (21). Irisin decreases pro-inflammatory cytokine release from adipose tissue and increases anti-inflammatory cytokine release (11). Therefore, increasing anti-inflammatory cytokine levels suppress chronic inflammation resulting from obesity (22). Irisin also decreases the expression of monocyte chemoattractant protein-1 (MCP$1)$, impairs the release and expression of leptin which is related to proinflammatory state, and increases adiponectin, which is an anti-inflammatory cytokine (23). Increased serum leptin level in obese individuals pose an important risk factor in terms of MetS and insulin resistance (24) by causing excessive energy intake and decreased energy expenditure (25). Adiponectin increases the sensitivity of cells to insulin. Serum concentration of adiponectin is low in obese individuals and it is inversely related to insulin resistance (25).

Conflicting results were obtained in studies examining the relationship of irisin with obesity. Studies showing an inverse relationship between adiposity and the concentration of circulating irisin have been reported in the literature $(26,27)$. Tang et al., (16) have shown that the irisin concentration decreases in overweight and obese individuals compared to individuals with normal body weight. This is attributed to the impaired PGC- $1 \alpha$ expression in muscle in obese individuals. Similarly, there was an inverse relationship between the circulating irisin and Body Mass Index (BMI) in other study (22). 
Some studies have shown that serum irisin levels are positively associated with BMI and adiposity. In two studies, it was shown that the serum irisin concentration of morbid obese patients was higher than that of normal and anorexic individuals $(28,29)$. This is explained by the fact that irisin resistance may have developed in obese individuals (29). Irisin resistance is defined as the increased irisin level in obese individuals to modulate the energy balance and maintain glucose homeostasis. Therefore, it is thought that hyperiricinemia seen in obese individuals may be a mechanism to maximize the anti-obesity and anti-hyperglycemic effects of the irisin hormone (30). Serum irisin level was positively associated with BMI in other studies $(31,32)$. There is also a study showing that the concentration of the irisin is not related to adiposity (33).

It has been reported that the level of circulating irisin decreases due to weight loss and causes a decrease in muscle mass (34). After bariatric surgery, it has been shown that the serum irisin level also decreases with body weight loss, which has been attributed to the decrease in lean body mass and FNDC5 mRNA levels $(11,35)$. However, decreased serum irisin status returned with the regain of body weight (11).

\section{Irisin\&Insulin Resistance}

Böstrom et al. discovered that irisin molecule has beneficial effects on glucose tolerance and reduces fasting insulin level in mice. After these findings other studies have been conducted to understand the association between irisin and insulin resistance and diabetes mellitus all over the world (20). In addition to the role of the irisin in maintaining the energy balance, it is also linked to obesity-related metabolic disorders such as insulin resistance and T2DM (36).

Irisin molecule acts as an insulin sensitizer since it increases glucose uptake into skeletal muscle and improves hepatic glucose and lipid metabolism (11). Irisin is considered to be an important option for the treatment of diabetes, as it increases insulin sensitivity, increases glycogenesis and decreases gluconeogenesis (Figure 1) (12).

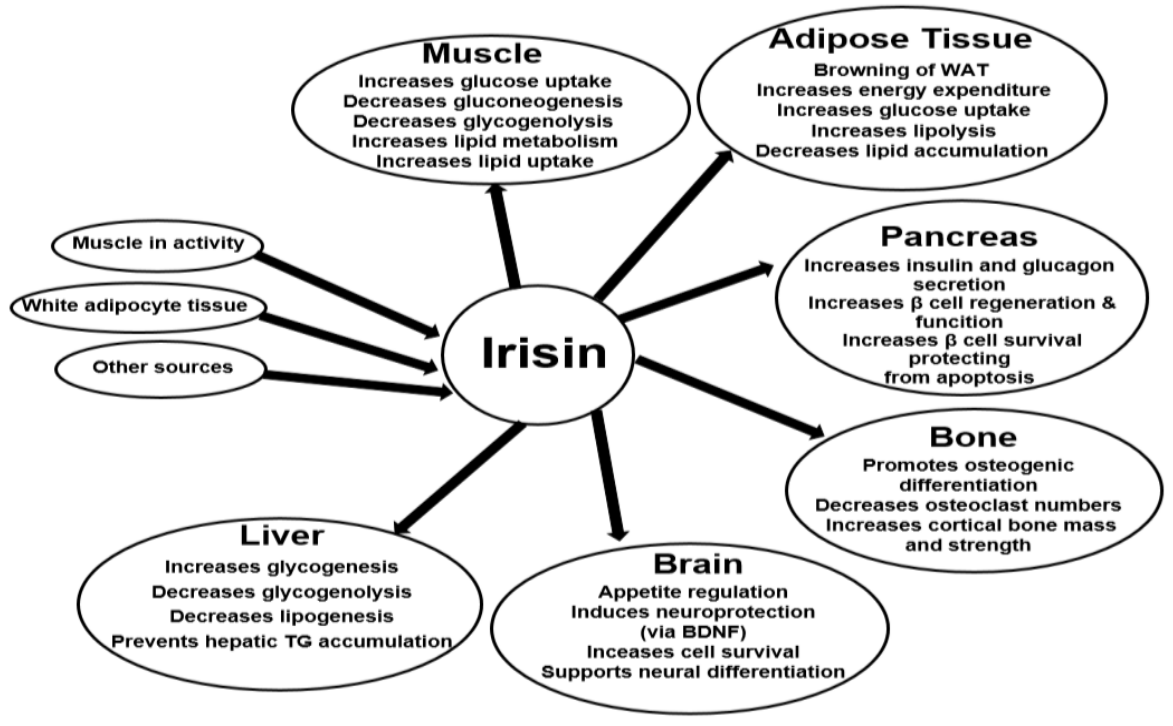

Figure 1. Functions of irisin molecule in various tissues and organs. WAT: White adipose tissue, BDNF: Brain derived neurotrophic factor. Adapted from $13^{\text {th }}$ reference. 
In addition, it has an important role in improving insulin resistance and maintaining glucose homeostasis by causing the browning of fat tissue (20). Also, it induces the continuation of the functions of beta cells in the pancreas by reducing the endoplasmic reticulum stress (11). Also irisin induces glucose uptake in skeletal muscles via AMPK-related pathways, which reveals the positive effects of irisin on glucose metabolism. Therefore, it is estimated that irisin may have possible effects on diabetes in the future (21). Additionally, irisin contributes the beta cell formation and induces increased beta cells number. It has been suggested that circulating irisin may play role in maintaining homeostasis, improving insulin resistance and diabetes mellitus (21).

Moreno et al., (26) have found that irisin concentration was negatively associated with insulin resistance in men. In studies conducted on individuals with T2DM (37) and gestational Diabetes Mellitus (38), it has been shown that serum irisin concentration was inversely related to the development of diabetes, considering that impairment of PGC- $1 \alpha$ expression may result in this in individuals with T2DM. Fasting insulin, HOMA-IR were inversely associated with irisin concentration (16, 39). Shoukry et al., (40) has found that serum irisin concentration was lower among individuals with new onset T2DM compared to healthy counterparts. Therefore, modulation of the irisin level has pivotal role on controlling obesity and various diseases associated with obesity (16).

Also positive association of irisin concentration and HOMA-IR, fasting insulin and blood glucose levels were reported in some studies. Studies have shown that insulin resistance is positively associated with serum irisin concentration $(41,42)$. In other study, it is reported that children with impaired glucose tolerance, had higher circulating irisin levels (43). Additionally, it has been considered that higher irisin concentration is because of the impairment of insulin sensitivity, lipid and glycose metabolism, suggesting that a potential feedback mechanism between irisin and adiponectin for higher energy consumption in the adipocytes (32).

\section{Irisin\&Metabolic Syndrome}

The results of the studies that examine the associations between irisin and MetS appear to be contradictory. It has been demonstrated that serum irisin levels decrease in children diagnosed with MetS $(44,45)$. It has been suggested that the irisin molecule may be a biomarker for the diagnosis of MetS in children in prepubertal period (44) and lower irisin concentration may worsen the metabolic disturbances among children with obesity and MetS (45). Decreased irisin concentration was associated with the emerge of increased MetS and fasting blood glucose level in obese adults $(46,47)$. On the other hand, Tabak et al., (15) have shown that there is a positive association between irisin level and MetS components including BMI, waist circumference and waist/hip ratio. It has also been suggested that the serum irisin concentration may be a biomarker for the development of MetS. In addition, there are studies showing that the level of circulating irisin is positively associated with total cholesterol (48) and inversely associated with HDL-C (49). It has been reported higher irisin concentration in children with MetS (50). In addition, it was shown that the serum irisin concentrations of individuals in the group with a diagnosis of MetS were 
higher compared to control group; this is attributed to the increased irisin resistance in adipose tissue (31). In the study of Tang et al., (16) a positive relationship was found between irisin and triglycerides; however, no relationship was found between total cholesterol and HDL-C and irisin.

\section{CONCLUSIONS}

Irisin which is expressed mainly from muscle tissue in response to exercise is PGC- $1 \alpha$ dependent, and its most important function is to increase energy expenditure by inducing thermogenesis via turning of white adipose tissue to brown adipose tissue. Although it is a new discovered hormone, various studies have been conducted on irisin until today. The irisin molecule is thought to be a potential therapeutic agent for treatment of many diseases, especially obesity and T2DM. Irisin is considered to be an important option for the treatment of diabetes as it increases insulin sensitivity, increases glycogenesis and decreases gluconeogenesis. In addition to regulating insulin resistance and maintaining glucose homeostasis, it also reduces endoplasmic reticulum stress thereby it provides the continuation of the functions of beta cells in the pancreas. In this review, the potential effects of the irisin molecule on metabolic disorders including obesity, insulin resistance and MetS were evaluated and the studies on this subject are reviewed. Even though there are contradictory results about irisin status in individuals with obesity, insulin resistance or MetS, irisin may have an important therapeutic target in the treatment of these metabolic abnormalities. It is also considered that the receptors of the irisin molecule, which have not been discovered and the knowing of the tissues where these receptors are located may be an important finding to understand underlying mechanisms of the association between circulating irisin concentration and metabolic disorders associated with obesity. There are still need for prospective or randomized controlled clinical trials involving large case series to elucidate the potential mechanisms and causal relationships to develop the new therapeutic approaches.

Author Contribution Statement: Idea / concept: HTB, AH; Design: HTB, AH; Supervision / consultancy: AH; Resource search: HTB, AH; Manuscript writing: HTB, AH; Critical review: AH

Conflict of Interest: "The authors declare that there is no conflict of interest".

\section{REFERENCES}

1. Obesity and overweight. Available at: https://www.who.int/news-room/factsheets/detail/obesity-and-overweight Accessed on September 21, 2020.

2. Tam CS, Xie W, Johnson WD, Cefalu WT, Redman LM, Ravussin E. Defining insulin resistance from hyperinsulinemic-euglycemic clamps. Diabetes Care. 2012;35(7):1605-1610.

3. Savaş HB, Gültekin F. İnsülin Direnci ve Klinik Önemi. SDÜ Tıp Fak Derg. 2017;24(3):116-125.

4. Bozkuş Y, Mousa U, Kırnap N, İyidir ÖT, Ramazanova L, Nar A, ve ark. Kadınlarda metabolik sendromun alternatif prediktörleri. Pam Tip Derg. 2020;13(2):341-349.

5. Hacışevki A, Berberoğlu HT. Activation of inflammatory signalling pathways in metabolic syndrome: Changes in Adipokines and Cytokines. In: Yücel D, editor. Current Biochemical Studies. Akademisyen Publisher, 2020. p:15-36.

6. Önal S. Egzersiz Hormonu: İrisin. Editör: Karaduman A, Ülger Ö, Vardar Yağlı, N, Kılınç Muhammed, Serel Arslan S. Fizyoterapistler ve Öğrenciler için e-kitap. H.Ü.S.B.F. Fizyoterapi ve Rehabilitasyon Bölümü Yayını. 2017. s: 34-41. 
7. Boström P, Wu J, Jedrychowski MP, Korde A, Ye L, Lo JC, et al. A PGC1- $\alpha$-dependent myokine that drives brown-fat-like development of white fat and thermogenesis. Nature. 2012;481(7382):463-468.

8. Grygiel-Górniak B, Puszczewicz M. A review on irisin, a new protagonist that mediates muscle-adipose-bone-neuron connectivity. Eur Rev for Med Pharmacol Sci. 2017;21(20):4687-4693.

9. Aslan NN, Yardımcı H. Obezite Üzerine Etkili Yeni Bir Hormon: İrisin. GÜSBD 2017;6(3):176-183.

10. Gülmez C, Atakişi O. Yeni Hormonlar: RSpondin-1, Nesfatin-1 ve İrisin. Cjoscience. 2019;6(1):37-50.

11. Arhire LI, Mihalache L, Covasa M. Irisin : A Hope in Understanding and Managing Obesity and Metabolic Syndrome. Front Endocrinol. 2019;10(524):1-12.

12. Korta P, Pocheć E, Mazur-Biały A. Irisin as a multifunctional protein: Implications for health and certain diseases. Medicina (Lithuania). 2019;55(8):1-14.

13. Aydin S. Three new players in energy regulation: Preptin, adropin and irisin. Vol. 56, Peptides. Elsevier Inc.; 2014. p. 94-110.

14. Irving BA, Still CD, Argyropoulos G. Does IRISIN Have a BRITE Future as a Therapeutic Agent in Humans? Curr. Obes. Rep. 2014;3(2):235-241.

15. Tabak O, Simsek G, Erdenen F, Sozer V, Hasoglu T, Gelisgen R, ve ark. The relationship between circulating irisin, retinol binding protein-4, adiponectin and inflammatory mediators in patients with metabolic syndrome. Arch Endocrin Metab. 2017;61(6):515-523.

16. Tang L, Tong Y, Zhang F, Chen G, Zhang YC, Jobin $\mathrm{J}$, et al. The association of circulating irisin with metabolic risk factors in Chinese adults: A cross-sectional community-based study. BMC Endocr. Disord. 2019;19(1):1-6.

17. İnci $A$, Ünübol Aypak S. İrisin ve Metabolik Etkileri. Turkiye Klinikleri Endocrin. 2016;11(1):15-21.

18. Castillo-Quan JI. From white to brown fat through the PGC-1 $\alpha$-dependent myokine irisin: Implications for diabetes and obesity. Dis Model Mech. 2012;5(3):293-295.

19. Bakan S, Acar Tek N. Enerji Harcamasının Düzenlenmesinde Hormonların Etkileri. ACU Sağlık Bil Derg. 2018;9(3):207-212.
20. Munoz IYM, Del Socorro Camarillo Romero E, De Jesus Garduno Garcia J. Irisin a novel metabolic biomarker: Present knowledge and future directions. Int. J. Endocrinol. 2018;7816806:1-8.

21. Gizaw M, Anandakumar P, Debela T. A review on the role of irisin in insulin resistance and type 2 diabetes mellitus. J. Pharmacopuncture. 2017;20(4):235-242.

22. Choi Y, Kim M, Bae K, Seo H, Jeong J, Lee W, et al. Serum irisin levels in new-onset type 2 diabetes. Diabetes Res Clin Pract. 2013;100(1):96-101.

23. Mazur-Bialy AI, Bilski J, Pochec E, Brzozowski T. New insight into the direct antiinflammatory activity of a myokine irisin against proinflammatory activation of adipocytes. Implication for exercise in obesity. J Physiol Pharmacol. 2017;68(2):243-251.

24. Maffei M, Halaas J, Ravussin E, Pratley RE, Lee GH, Zhang Y, et al. Leptin levels in human and rodent: Measurement of plasma leptin and ob RNA in obese and weight-reduced subjects. Nat Med. 1995;1(11):1155-1161.

25. Choi CHJ, Cohen P. Adipose crosstalk with other cell types in health and disease. Exp Cell Res. 2017;360(1):6-11.

26. Moreno-navarrete M, Ortega F, Serrano M, Guerra E, Pardo G, Tinahones F, et al. Irisin Is Expressed and Produced by Human Muscle and Adipose Tissue in Association With Obesity and Insulin Resistance. J Clin Endocrinol Metab. 2013;98(4):E769-778.

27. Liu B-W, Yin F-Z, Qi X-M, Fan D-M, Zhang Y. The Levels of Serum Irisin as a Predictor of Insulin Resistance in Han Chinese Adults with Metabolically Healthy Obesity. Clin Lab. 2017;63(05+06/2017):881-886.

28. Stengel A, Hofmann T, Goebel-Stengel M, Elbelt U, Kobelt P, Klapp BF. Circulating levels of irisin in patients with anorexia nervosa and different stages of obesity-Correlation with body mass index. Peptides. 2013;39:125-130.

29. Pardo M, Crujeiras AB, Amil M, Aguera Z, Jiménez-Murcia S, Baños R, et al. Association of irisin with fat mass, resting energy expenditure, and daily activity in conditions of extreme body mass index. Int $\mathbf{J}$ Endocrinol. 2014;2014:857270. 
30. Perakakis N, Triantafyllou GA, FernándezReal JM, Huh JY, Park KH, Seufert J, et al. Physiology and role of irisin in glucose homeostasis. Nat Rev Endocrinol. 2017 Jun;13(6):324-337.

31. Park KH, Zaichenko L, Brinkoetter M, Thakkar B, Sahin-Efe A, Joung KE, et al. Circulating Irisin in Relation to Insulin Resistance and the Metabolic Syndrome. J Clin Endocrinol Metab. 2013;98(12):4899-4907.

32. Huh JY, Panagiotou G, Mougios V, Brinkoetter M, Vamvini MT, Schneider BE, et al. FNDC5 and irisin in humans: I. Predictors of circulating concentrations in serum and plasma and II. mRNA expression and circulating concentrations in response to weight loss and exercise. Metab.: Clin. Exp. 2012;61(12):1725-1738.

33. Shi X, Lin M, Liu C, Xiao F, Liu Y, Huang P, et al. Elevated circulating irisin is associated with lower risk of insulin resistance: Association and path analyses of obese Chinese adults. BMC Endocr Disord. 2016;16(1):44.

34. Huh JY, Dincer F, Mesfum E, Mantzoros CS. Irisin stimulates muscle growth-related genes and regulates adipocyte differentiation and metabolism in humans. Int $\mathrm{J}$ Obes. 2014;38(12):1538-1544.

35. Young Huh J, Panagiotou G, Mougios V, Brinkoetter M, Vamvini MT, Schneider BE, et al. FNDC5 and irisin in humans: I. Predictors of circulating concentrations in serum and plasma and II. mRNA expression and circulating concentrations in response to weight loss and exercise. Metabolism. 2012;61(12):1725-1738.

36. Swick AG. Irisin, a novel myokine: Potential role in obesity and diabetes. Heart Metab. 2013;61:39-40.

37. Liu JJ, Wong MDS, Toy WC, Tan CSH, Liu S, $\mathrm{Ng} \mathrm{XW}$, et al. Lower circulating irisin is associated with type 2 diabetes mellitus. J Diabetes Complications. 2013 Jul;27(4):365369.

38. Yuksel MA, Oncul M, Tuten A, Imamoglu M, Acikgoz AS, Kucur M, ve ark. Maternal serum and fetal cord blood irisin levels in gestational diabetes mellitus. Diabetes Res Clin Pract. 2014;104(1):171-175.
39. Yan B, Shi X, Zhang H, Pan L, Ma Z, Liu S, et al. Association of serum irisin with metabolic syndrome in obese chinese adults. PLoS ONE. 2014;9(4):e94235.

40. Shoukry A, Shalaby SM, El-Arabi Bdeer S, Mahmoud AA, Mousa MM, Khalifa A. Circulating serum irisin levels in obesity and type 2 diabetes mellitus. IUBMB Life. 2016;68(7):544-556.

41. Sesti G, Andreozzi F, Fiorentino TV, Mannino GC, Sciacqua A, Marini MA, et al. High circulating irisin levels are associated with insulin resistance and vascular atherosclerosis in a cohort of nondiabetic adult subjects. Acta Diabetol. 2014;51(5):705-713.

42. Lopez-Legarrea P, De La Iglesia R, Crujeiras AB, Pardo M, Casanueva FF, Zulet MA, et al. Higher baseline irisin concentrations are associated with greater reductions in glycemia and insulinemia after weight loss in obese subjects. Nutr. Diabetes. 2014;4(2):e110.

43. Reinehr T, Elfers C, Lass N, Roth CL. Irisin and its relation to insulin resistance and puberty in obese children: A longitudinal analysis. J Clin Endocrinol Metab. 2015;100(5):21232130.

44. Shim YS, Kang MJ, Yang S, Hwang IT. Irisin is a biomarker for metabolic syndrome in prepubertal children. Endocr J. 2018;65(1):2331.

45. Gonzalez-Gil AM, Peschard-Franco M, Castillo EC, Gutierrez-Delbosque G, Treviño V, Silva-Platas C, et al. Myokine-adipokine cross-talk: Potential mechanisms for the association between plasma irisin and adipokines and cardiometabolic risk factors in Mexican children with obesity and the metabolic syndrome. Diabetol Metab Syndr. 2019;11(1):1-16.

46. Yan B, Shi X, Zhang H, Pan L, Ma Z, Liu S, et al. Association of Serum Irisin with Metabolic Syndrome in Obese Chinese Adults. PLoS ONE. 2014;9(4):e94235.

47. Al-Daghri NM, Alkharfy KM, Rahman S, Amer OE, Vinodson B, Sabico S, et al. Irisin as a predictor of glucose metabolism in children: Sexually dimorphic effects. Eur J Clin Invest. 2014;44(2):119-124. 
48. Oelmann S, Nauck M, Völzke H, Bahls M, Friedrich N. Circulating irisin concentrations are associated with a favourable lipid profile in the general population. PLoS ONE. 2016;11(4):e0154319.

49. Buscemi S, Corleo D, Vasto S, Buscemi C, Massenti MF, Nuzzo D, et al. Factors associated with circulating concentrations of irisin in the general population cohort of the ABCD study. Int J Obes. 2018;42(3):398-404.
50. de la Iglesia R, Lopez-Legarrea P, Crujeiras AB, Pardo M, Casanueva FF, Zulet MA, et al. Plasma irisin depletion under energy restriction is associated with improvements in lipid profile in metabolic syndrome patients. Clin Endocrinol. 2014 Aug 1;81(2):306-311. 